\title{
'Ofre, skurke og frelsere': Danske fortællinger om køn, race og menneskehandel
}

\section{Af Christian Groes-Green}

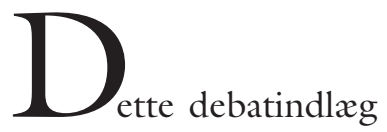

undersøger, hvad mediers historier om handel med kvinder siger om den danske selvforståelse ved at sammenligne diskursen om den hvide slavehandel i årene fra 1870 til 1925 med diskursen om menneskehandel i nyere tid. Hvordan konstrueres danskhed, race og køn i den offentlige debat, og hvad siger disse konstruktioner om forholdet mellem 'os' og 'de fremmede'? Vi ved endnu ganske lidt om, hvad menneskehandel indebærer, og forskningen har pga. de store metodiske udfordringer, man står overfor, vanskeligt ved at forklare dens årsager eller angive dens omfang (Andreas og Greenhill 2010). Men der er næppe nogen tvivl om, at menneskehandel og tvungen migration er et alvorligt globalt problem, som vi som forskere må gøre alt for at afdække og forstå gennem grundige empiriske undersøgelser af migrationsprocessen. I dette debatindlæg er det dog ikke mit ærinde at diskutere omfanget eller karakteren af menneskehandel, eller hvordan vi bekæmper fænome- 
net. Derimod ønsker jeg at sætte fokus på, hvad menneskehandelsdiskursen herhjemme siger om den danske selvforståelse.

Inspireret af komparative analyser af 'den hvide slavehandel' og nutidens 'menneskehandel' bedrevet af kultur- og socialforskere i England og USA (Doezema 2010; Day 2010; Weitzer 2007) sætter jeg fokus på, hvordan 'de fremmede' i begge perioder konstrueres som enten skurke eller ofre, mens europæere, i dette tilfælde danskerne, konstrueres som frelserne. Sociologer og antropologer har påvist, hvordan følelsesladede og maleriske historier om 'sexslaver', der bortføres fra fattige lande til Europa, risikerer at skygge for en dybere forståelse af sammenhængen mellem global ulighed, Europas lukkede grænser og fattige kvinders migration til den velhavende del af verden (Agustin 2007). Andre peger på, at køn- og racestereotype billeder af menneskehandel tjener en strammere indvandringspolitik og en øget politiindsats over for prostitution (Sharma 2003).

\section{KVINDEHANDEL DENGANG:}

HVIDE, USKYLDSRENE KVINDER

Under overskriften "Salg af kvinder til Amerika", skrev Vendssyssel Tidende i 1881:

Fra pålidelig kilde har vi fået underretning om hvorledes en pige fra Hjørring-egnen er blevet solgt til og gift med en neger i Amerika (Citeret efter Madsen 2008: 19).

Af denne og lignende historier i dansk presse fra den tid fremgår det, at stadigt flere hvide danske kvinder rives ud af deres trygge landlige tilværelse og sendes til farlige storbyer som New York, Skt. Petersborg, Buenos Aires og Istanbul. Flere historier bygger på en generel frygt for, at 'de fremmede' skal komme til landet og bortføre uskyldige kvinder. Således bidrager de til at ophøje den danske kvinde til det absolutte offer for kyniske mænd i en demoraliseret moderne verden. Danske kvinder skildres enten som naive piger eller som stakkels skøger, der passivt lader sig transportere af sorte og/eller sexhungrende mænd, der behandler dem som handelsvarer. Omtrent samtidig med historien fra Vendsyssel advarer en avis i København om en usynlig trafik af kvinder gennem såkaldte agenturer:

Der eksisterer her i byen et eller flere agenturer for handel med hvide slaver. Fra og gennem vor hovedstad forsynes en stor del af Rusland med hvide skøger. Kvinder lokkes i stort tal gennem disse agenturer under forskellige påskud til de russiske byer hvor de anbringes på utugtshuse. Politiet som har fået nys herom, har ikke kunnet finde de skyldige (Citeret efter Madsen 2008: 45).

Mens dramaet udfoldede sig i medierne, og panikken bredte sig i danske storbyer og $\mathrm{i}$ provinsen, var der stadig få konkrete beviser. Der er dog ingen tvivl om, at fattige danske kvinder på det tidspunkt i højere grad end tidligere drog ud i verden for at tjene til føden eller søge lykken. Fra Rusland og USA kom historier om danskere, som havde fået arbejde på beværtninger og varieteer - flere af dem endda på bordel. Men mange opfattede det nye migrationsfænomen, hvor kvinder rejste sammen eller alene ud i verden for at arbejde i fremmede storbyer, som mistænkeligt og uforståeligt. Opfattelsen blandt det debatterende borgerskab var, at ingen kvinder frivilligt ville rejse ud i verden på egen hånd, fordi dette jo ville være farligt og dumdristigt. Da der samtidigt var flere udlændinge, der rejste til Danmark, opstod den fordom, at det måtte være en international gruppe af forbrydere og slavehandlere, der stod bag, og som med forførelseskunst og falske løfter lokkede kvinderne ud af landet. Historierne voksede eksplosivt, og deres dramatiske budskaber bevirkede, at borgerskabet og kristne foreninger, der så sig selv som dydens vogtere, krævede politisk handling. I avisers forklaringer af fænomenet knyttedes handlen med kvinder sammen med farerne ved 
storbylivet, dets seksuelle løssluppenhed og sædernes generelle forfald. Det var endvidere underforstået i historierne, at kvinder var mere sårbare over for rejsens og storbyens fælder, da kvinder var mere godtroende, uvidende og føjelige end mænd (Madsen 2008). På et tidspunkt besluttedes det derfor fra politisk hold, at danske kvinder, der var rejst til udlandet for at arbejde og havde forladt deres familier eller mænd, skulle opspores og hjælpes tilbage til Danmark. Der kom samtidig fokus på de bureauer, der formidlede arbejde som tjenere, dansere eller sangere. En annonce lød således:

Sangerinder til Rusland. Unge, blonde, velskabte damer med sangstemme kunne få engagement til Rusland ved henvendelse til fru Martini, Petersens passage (Citeret efter Madsen 2008: 49).

Politiet gjorde sit for at komme problemet til livs, men forhør af damer som fru Martini bar sjældent frugt. Der manglede vidneudsagn og beviser for, at kvinder var blevet bedraget eller bortført. Historiske studier har vist, at kvinder overalt i Europa tilsyneladende rejste af egen vilje og sjældent ytrede ønsker om at komme tilbage til deres oprindelseslande (Doezema 2010), og det samme gjaldt for de danske kvinder, der rejste udenlands (Madsen 2008). I kølvandet på frygten for hvid slavehandel steg befolkningens frygt for fremmede mænd, særligt dem, som viste interesse for danske kvinder. For eksempel lød det således i Vejle Amts Avis i 1909:

For nogle uger siden kom en ca. 40 årig, elegant klædt mand her til Vejle, det meste tid af dagen opholdt han sig på en af vores strøgcafeer. På cafeen sad han imidlertid og vaagede nøje over de forbipasserende unge piger (Citeret efter Madsen 2008: 59).

Vidner berettede, at den fremmede mand så en pige, som han henvendte sig til. Avisen skrev:
Fra den dag kunne hun næsten ikke komme på gaden uden at han var i hælene på hende og inviterede hende på cafe, i teater eller i variete (Citeret efter Madsen 2008: 59).

Der blev sendt bud efter politiet, og i avisen rapporterede journalisten om et stort drama, uden dog at få bekræftet historien:

Ved at gå ham på klingen fik politiet oplyst at han var en gemen kvindehandler der prøvede at skaffe piger til utugtshuse i Argentina. Det navn han opgav var falsk, hans skæg ligeså.

Forbryderen, der påstod at være fra Stavanger sidder nu i Holstebro Arrest. Foreløbig er det oplyst at en 16 år gammel pige fra Struer have indvilliget $i$ at rejse med ham, men heldigvis var hun endnu ikke afrejst da slynglen blev sat fast (Citeret efter Madsen 2008:61).

Dagen efter kom der et kort dementi i samme avis:

Det viser sig, at vor meddelers beretning om en kvindehandler der havde været på spil i Vejle, ikke er korrekt i sine enkeltheder (Citeret efter Madsen 2008: 61).

Nogle måneder senere bragte Politiken endnu en reportage om de farlige fremmede:

En mystisk Tyrk med et mindre tillidsvækkende ydre indlogerede sig i forgårs på hotel Metropol på Rådhuspladsen. Han var øjensynlig en stor dameven. En anden velmenende mand der tilfældigvis havde haft lejlighed til at iagttage tyrken gav komiteen til bekæmpelse af den hvide slavehandel et vink (Citeret efter Madsen 2008:89).

En 18-årig kvinde havde indvilliget i at rejse med 'tyrken', men uden familiens accept. Det fik Komiteen til Bekæmpelse af Den Hvide Slavehandel til at skride ind og overtale politiet til at anholde den mørke dameven og redde den unge uvidende kvinde, som dog ikke var enig i, at manden 
ville bortføre hende eller sælge hende som slave:

Da hun gjorde mine til at gå, måtte politimanden erklære hende anholdt, hvad hun i sin uerfarenhed var meget vred over (Citeret efter Madsen 2008: 93).

Som eksemplerne illustrerer, ansås 'mørke mænd' i Danmark for at have skjulte bagtanker om at stjæle landets kvinder og sælge dem som slaver til utugtshuse. De går mistænkeligt klædt, har et mindre tillidsvækkende ydre og er seksuelt indladende over for danske kvinder. Men som i mange andre historier fra den tid stod en velmenende dansk mand og politiet klar til at redde og beskytte den naive kvinde, i dette tilfælde støttet af en stadig mere indflydelsesrig Komite til Bekæmpelse af Den Hvide Slavehandel. Det var under inspiration fra lignende komiteer i Europa at den danske pendant blev stiftet i 1902. Den danske komité vandt opbakning fra Foreningen til Forvildede Unge Pigers Frelse og Foreningen imod Lovbeskyttelse for Usædelighed og Den Indre Mission i København. Sidstnævnte var ophavsorganisationen for KFUK Reden, som i dag er en kristen hjælpeorganisation for gadeprostituerede på Vesterbro. Alle bekæmpede disse organisationer den statsregulerede prostitution og fordærvelsen af samfundets moral (Madsen 2008). Kampen mod utugtige mænd, der købte sex, og forestillingen om kvinders sårbarhed og hjælpeløshed blev brugt som begrundelser for at forhindre kvinder i at rejse ud i verden på egen hånd. De skulle oplyses om faren ved at rejse uden følgeskab af en mandlig beskytter, en hvid dansk mand med hjertet på rette sted forstås. I det hele taget italesatte historierne modernitetens trusler mod Europas gamle traditioner: $x g-$ teskabet, kristendommen og det nationale fællesskab. Gennem en mobilisering af en rakke organisationer mod prostitution og kvindehandel skulle den truede kultur beskyttes mod sexlivets kommercialisering og de fremmede mænd, og fædrelandets piger skulle blive hjemme (Day 2010).

I begyndelsen af 1900-tallet tog historierne til i antal og dramatik. De nåede deres klimaks i teaterstykker, film og bøger om grove udnyttelser af hvide kvinder $\mathrm{i}$ fremmede lande (Madsen 2008; Doezema 2010). Men så skete der noget mærkværdigt. I 1906 begyndte avisen Politiken at sætte spørgsmålstegn ved, om det, komitéen bekxmpede, rent faktisk havde med hvid slavehandel at gøre. Andre medier fulgte trop, og journalister undersøgte disse historier nærmere. Langt de fleste historier viste sig at være særdeles overdrevne, omfanget af danske kvinders emigration var minimalt, og forsvundne kvinder var blevet fundet. En avisoverskrift i 1911 lød således: "Den hvide slavinde fundet i Bagsværd". I årene, der fulgte, ebbede historierne ud, politiet fik ikke flere sager og 'den hvide slavehandel' blev i den offentlige bevidsthed reduceret til en 'folkekomedie', som ingen længere tog særligt seriøst (Madsen 2008: 115).

\section{KVINDEHANDEL I DAG:}

FREMMEDE, FARVEDE KVINDER

Der gik yderligere 80 år før historier om kvindehandel for alvor atter dukkede op i de danske medier. Men til forskel fra i 1800-tallet var der i 1990'erne fokus på fremmede, farvede kvinder, der frygtedes og stadig frygtes handlet til Europa, frem for hvide kvinder, der handledes til udlandet. Der florerer dramatiske beretninger om kvinder, der lever som 'sexslaver' på de københavnske gader og 'onde bagmænd' fra fjerne lande, som holder dem i et jerngreb. Historierne er siden taget til og har ført til en drastisk stigning i den danske regerings og hjælpeorganisationers bekæmpelse af frnomenet (Socialministeriet 2011). Lad mig illustrere det kraftigt øgede fokus i offentligheden med en opgørelse over det stigende antal historier om menneskehandel i medierne. Ved en gennemgang 
af overskrifterne i aviserne Ekstra Bladet, Berlingske Tidende og Politiken, hvis artikler har været registreret i Infomedia siden 1990, kan man se, at der fra 1990 til 1999 var 18 artikler, hvor ordene 'menneskehandel', 'kvindehandel' eller 'sexslaver' indgik. Fra 2000 til 2010 var det tal oppe på 179 artikler. I år 1999 var antallet af historier om 'menneskehandel', 'kvindehandel' eller 'sexslaver' i alle danske medier 120 og i 2010 var det tal steget til 2617. Og i alt var der fra 1995 til år 2000457 artikler som indeholdt de nævnte ord, mens der fra 2005 til 2010 var 12.288 (Egne udregninger ud fra Infomedia). Uanset at der skulle være enkelte medier, som ikke var repræsenteret i Infomedia i midt-halvfemserne, eller at der er kommet flere medier til siden, er der ingen tvivl om, at mediernes behandling af disse emner er steget eksponentielt. Selvom det ikke kan udelukkes, at antallet af ofre for menneskehandel eller antallet of forsøg på udnyttelse er stigende, kan dette heller ikke verificeres fra officielt hold i hverken FN eller det amerikanske udenrigsministerium, hvorfra de fleste estimater om fænomenets omfang stammer (Andreas og Greenhill 2010). Til gengæld viser opgørelsen ovenfor og en række diskursanalyser af debatterne $\mathrm{i}$ andre europxiske lande, at der aldrig har været så stor fokus på menneskehandel som netop nu (Day 2010).

Der er som sagt ingen tvivl om, at kvinder, der migrerer til vores del af verden som sexsælgere, udsættes for en række risici i migrationsprocessen, og at nogle bedrages, trues eller udnyttes undervejs. Spørgsmålet er dog, hvorfor angivelsen af menneskehandelens omfang ofte overdrives af bestemte aktører, og hvorfor de involverede beskrives så stereotypt, som tilfældet er.

\section{VM I STEREOTYPER:}

\section{NÅR FODBOLD SKABER SEXPANIK}

Lad os se nærmere på de konkrete historier, som foldede sig ud i danske medier i forbindelse med fodbold-VM. Forud for VM i
Tyskland i 2006 førte 3F og Socialdemokraterne en storstilet kampagne mod kvindehandel. Anledningen var, at man frygtede, at mellem 40.000 og 100.000 kvinder ville blive handlet til de tyske storbyer (Sæhl 2006). Tallene kom fra EU, som angivelig havde dem fra NGO'er der bekæmpede prostitution og menneskehandel internationalt, men uden konkrete kilder eller angivelser af, hvordan man var kommet frem til disse efterretninger (EU 2010). Det tyske politi tog problemet meget alvorligt og afsatte flere tusinde betjente til at finkæmme storbyernes 'red light districts', før og under VM. Politi og myndigheder fandt $\mathrm{i}$ alt fem kvinder, som mistænktes for at være ofre for menneskehandel, men der var ingen beviser, og sagerne blev afvist ved retten (IOM 2006). Siden blev både politi, myndigheder og EUs politikere enige om, at historierne var ude af proportioner, og selv organisationen Global Alliance Against Trafficking in Women skrev en rapport i 2011, der beskrev, hvordan overdrivelser kan ende med at skade de kvinder, man ønsker at redde, hvis politiindsatsen blot fører til arrestationer og deportationer. Som eksempel på de forestillinger om menneskehandel, som florerede i medierne forud for VM i Tyskland, lød en historie i Weekendavisen således:

Mens verdens mest feterede fodboldstjerner i de kommende uger fryder og fornøjer deres fans på de tyske fodboldstadions, vil millionerne strømme ind på deres i forvejen velspækkede konti. Samtidig må verdens mest ydmygede kvinder slide mindst lige så hårdt $\mathrm{i}$ det på de tyske bordeller for at tilfredsstille den ene sexkunde efter den anden uden at få andet end håndører for det. Og mens fodboldstjernerne håber at deres agent kan få en klubpræsident til at skrive under på den næste fede millionkontrakt, frygter kvinderne at voldelige og kyniske bagmænd skal tvinge dem til at underskrive endnu et gældsbrev, der stavnsbinder dem til sexindustrien. Flere tusind kvinder fra baltiske, østeuropæiske, asi- 
atiske og afrikanske lande bliver transporteret til de tyske byer af kriminelle netværk, der tjener kassen på at tvinge dem til sex med de titusindvis af liderlige mænd, der hver dag står parat med åben gylp og tegnebog (Rothstein 2006).

Under overskriften "VM i kvindehandel" beskrev journalisten en forestillet virkelighed, som senere viste sig at være mere nuanceret, og frygten for at flere tusinde kvinder skulle handles til Tyskland, viste sig ikke at blive bekræftet. Artiklen satte fokus på 'hvide mænd', der udnytter 'fremmede kvinder' seksuelt, og 'bagmænd', der handler dem for økonomisk vindings skyld. De rige mænds fryd, fornøjelse og fede kontrakter kontrasteres med fattige kvinders ydmygelse, tvang og økonomiske slaveri. Mændene fremstår kyniske, mens kvinderne er frygtsomme. Mændene er aktive, som enten købere eller sælgere, kvinderne er objekter, der passivt transporteres. Hverken denne eller andre journalister bragte nyheden om, at antallet af formodede handlede kvinder var milevidt fra det omfang, de havde beskrevet forud for VM, og at deres gruopvækkende historier dermed ikke kunne bekræftes med eksempler fra virkelighedens verden. Man skulle tro, at medierne ville tage ved lære af at have skudt så langt over mål. Men fire år efter i forbindelse med VM i Sydafrika i 2010 gentog de overdrevne historier sig. Under overskriften "VM i sex og menneskehandel" skrev en journalist i Dagbladet Information:

VM i fodbold i Sydafrika giver ligesom sidst frygt for, at kvinder og børn bliver trukket over grænsen for at arbejde som prostituerede. Ved VM i Berlin skød kampagnerne mod kæmpe-bordeller og tvangsprostituerede langt over mål. I Sydafrika er der noget om snakken (...) På en lille bakke, en times kørsel uden for Mozambiques hovedstad, sidder mænd, kvinder og børn og lytter til musik. Den lave eftermiddagssol sender varme stråler ned i mylderet af brun hud og farvestrålende tøj. På scenen i midten står danske Caroline Henderson (...). Alt ånder idyl. I virkeligheden er vi midt i en kampagne mod trafficking og seksuel udnyttelse. Kendte studieværter og musikere opfordrer folk til at få øjnene op for, hvad der sker omkring dem. Minder dem om, at børn har ret til et trygt liv uden vold og seksuelle overgreb, og at vi skal passe på hinanden (Rørbech 2010).

Ligesom i 2006 var budskabet, at vi skal åbne øjnene for verdens skjulte rædsler, for verden er ikke idyllisk. Verden, ikke mindst den afrikanske, er farlig, særligt for kvinder og børn. Det er derfor, at vi hvide (danskere) skal gribe ind for at redde udsatte sorte kvinder. Flere vestlige og danske medier anslog, at mellem 40.000 og 100.000 ofre for menneskehandel ville komme til Sydafrika (Hope for the Sold 2010). Efter VM fastslog menneskerettighedsorganisationer imidlertid, at der ikke havde været en stigning $i$ antallet af sexarbejdere, og ingen ofre for menneskehandel var blevet identificeret (Gould 2010). Dette fik dog ikke medierne herhjemme til at bringe et dementi. Et nyere eksempel på en overdrivelse, som ingen konsekvenser har fået, var da Reden International (en del af KFUK) var kilde til informationer i avisen MetroXpress om, at organisationen havde haft kontakt med 3625 handlede kvinder på deres mødested i 2011, og at dette var en fordobling i forhold til året før (Tromborg 2012). Det fremgår dog tydeligt af det statslige Center mod Menneskehandels statistik for 2011, at der faktisk kun blev identificeret et (1) offer for menneskehandel i 2011 i forbindelse med det mødested, som Reden International driver (Center mod Menneskehandel 2012: 10). Der kom siden en beklagelse af disse forkerte tal på Reden Internationals hjemmeside, men moderorganisationen KFUK's sociale arbejde refererer stadig til artiklen i MetroXpress på dens hjemmeside, og MetroXpress har endnu ikke dementeret historien.

Selvom der findes et utal af eksempler på 
disse overdrivelser, kommer historierne om menneskehandel naturligvis ikke ud af det blå. Der findes veldokumenterede historier om tvang, vold og økonomisk udnyttelse i migrationsprocessen mod den vestlige verden (Andrijasevic 2010). Men spørgsmålet er, hvem der har gavn af at overdrive fænomenets omfang og ignorere spørgsmål om migration, fattigdom og global ulighed til fordel for generaliserende diskurser om 'os' og 'dem', om 'svage kvinder' og 'onde mænd', om 'sydlige landes rædsler' og 'dansk anstændighed'? Flere forskere har påpeget, hvordan frygten for menneskehandel bruges som en politisk platform i kampen imod bl.a. øget indvandring og imod prostitution (Weitzer 2007). Efter George W. Bush kom til magten i USA i 2001, mobiliseredes den radikale amerikanske kvindebevægelse, herunder Coalition Against Trafficking in Women (CATW), for at kræve en større indsats over for prostitution, der ansås som selve grundlaget for menneskehandel. Ligesom i slutningen af 1800-tallet, hvor amerikanske og europæiske komitéer til bekæmpelse af den hvide slavehandel satte dagsordenen, var CATW's hovedargument for bekæmpelsen af prostitution, at $k ø b$ og salg af sex grundlæggende er forbundet med vold, voldtægt og slaveri. Velvidende at præsident Bush var nykristen og en ivrig modstander af alle former for usædelighed, kom konservative og religiøse kræfter på banen og forstærkede deres kamp mod prostitution, som de anså som symbolet på USA's moralske forfald. Det lykkedes disse to grupperinger, altså kvindeorganisationer og kristne, at indgå en usædvanlig alliance og overtale Bush-administrationen til at indføre en skrappere politik vedrørende prostitution og menneskehandel. I forhandlingen om en ny værdipolitik blev spørgsmålet om menneskehandel en vigtig løftestang. Uden et eksplicit krav om videnskabelig evidens accepterede Bush-regeringen NGO'ernes høje estimater om problemets globale omfang samt deres vidtrækkende løsningsforslag (Andreas og
Greenhill 2010). En af løsningsmodellerne blev at gøre det til en betingelse for at modtage udviklingsbistand fra USA, at fattige lande bekæmper prostitution og ikke støtter sexarbejderorganisationer (Andreas og Greenhill 2010). Den udvikling, som blev sat i gang i USA i 2001, har haft vidtrækkende konsekvenser overalt i verden herunder i Danmark, hvor stadig flere kvinde- og hjælpeorganisationer ligeledes er begyndt at sætte lighedstegn mellem prostitution og menneskehandel, bl.a. med henblik på at skaffe ideologisk opbakning til at kriminalisere 'købesex' (Spanger 2011).

\section{OFRENE, SKURKENE OG FRELSERNE: DEN HVIDE NATIONS BESKYTTELSE}

Trods vidt forskellige historiske kontekster har fortællinger om kvindehandel dengang og i dag det til frelles, at de tegner et entydigt billede af mænd som skurke, af udenlandske kvinder som sårbare ofre, og af os selv, altså danske kvinder og mænd, som frelserne. Men hvor fokus i diskursen om den hvide slavehandel var på de fremmede mænd, som kom og lokkede danske kvinder til prostitution i fjerne lande, er problemet $\mathrm{i}$ vore dages menneskehandelsdiskurs mænd som sådan, eller rettere de mænd som hævdes ikke at kunne styre deres lyst til sex, og som køber uskyldige kvinders kroppe. I begge diskurser udelades spørgsmålet om kvinders egne syn på frivillighed og tvang, deres valg og motiver og de strukturelle forhold som gør dem sårbare.

I dag som dengang afspejler historierne en række migrationsfænomener, der, som nævnt tidligere, er veldokumenterede. Men hvor den offentlige panik dengang udsprang af, at danske kvinder på egen hånd rejste ud på en farefuld færd til fjerne storbyer, udspringer vore dages panik formentlig af historier om den sorte eller fattige kvinde, der rejser til vores storbyer, hvor de i kraft af deres synlighed på gader og pladser påkalder sig vores opmærksomhed og stillingtagen. Kvindernes salg af sex på åben 
gade fremkalder vores indignation og ønsket om at hjælpe, mens tilstedeværelsen af fremmede mænd i højere grad skaber utryghed og frygt, og disse mænd fremstilles ikke sjældent som tyve, pushere eller bagmænd. Det er muligt, som Jo Doezema hævder, at den skærpede opmærksomhed på 'menneskehandel' afspejler behovet for en ny fortælling, en ny fjende af Vesten, som vi alle kan enes om at bekæmpe, noget der repræsenterer det onde i verden efter de store fortællingers kollaps: kapitalismen, patriarkatet, de kriminelle, mafiaen. Som hun påpeger $\mathrm{i}$ sin sammenligning af den hvide slavehandel og konstruktionen af 'sex trafficking', har historierne også i dag en national såvel som patriarkalsk dimension. De appellerer til fredrelandet om at redde sårbare kvinder uden xgtemand og familie og uden den hvide nations beskyttelse (Doezema 2010).

Det, som vore dages ideologiske kamp mod menneskehandel skygger for, er imidlertid, at langt de fleste udenlandske kvinder, der sælger sex, har en fattig familie derhjemme, og at det ofte er forpligtelsen over for den, som motiverer deres migration (Kempadoo 2005). Som nyere forskning viser, er mange sexarbejdermigranter flygtet fra en situation af fattigdom og manglende adgang til job og ressourcer, hvor de trodser risici for udnyttelse, bedrag og tvang for at få et bedre liv og hjælpe deres fattige slægtninge i hjemlandet, selvom de ofte sjældent opfatter sexarbejde som deres fortrukne job hvis de havde haft andre muligheder (Andrijasevic 2010). Ifølge selvsamme forskning er langt størstedelen af de udenlandske kvinder fra Nigeria, Østeuropa eller Asien, der kommer til Danmark, ikke blevet narret ind i prostitution, og de er heller ikke nødvendigvis underlagt en bagmand (Spanger 2011; Holm 2006). Men kvinders migration mod Europa kan alligevel godt ses som tvungen, blot på et mere strukturelt niveau. Ofte bunder deres mi- gration nemlig i dyb fattigdom og global skævhed, der bevirker, at de søger mod rigere lande $\mathrm{i}$ håb om at tjene penge og hjælpe deres familier. Den fattigdom, som tvinger migranterne nordpå, er vi, 'de danske frelsere', ikke uden skyld i. Det er bl.a. den neoliberale udviklingspolitik, som vestlige lande fører rundt om i verden, der er med til at fastholde den globale ulighed mellem 'deres' lande og 'vores' lande (Sharma 2003). Fortællinger om ofre, skurke og frelsere gør næppe den store forskel i forhold til at xndre de globale og sociale vilkår, som skaber grobunden for menneskehandel. $\mathrm{Og}$ en hårdere politiindsats over for udlændinge i prostitutionsmiljøet, overvågning ved grænserne eller andre kriminologiske tiltag vil heller ikke ændre ved det faktum, at Europas lukkede grænser og manglende rettigheder til migrantkvinder er de primære grunde til deres sårbarhed over for andres forsøg på at lukrere på deres fattige baggrund, illegale migrantstatus og udelukkelse fra Europa.

\section{LITTERATUR}

- Agustin, Laura (2007): Sex at the Margins: Migration, Labour Markets and the Rescue Industry. Zed Books, London.

- Andreas, Peter og Greenhill, Kelly (2010): Sex, Drugs and Body Counts. Cornell University Press, Ithaca (NY).

- Andrijasevic, Rutvica (2010): Migration, Agency and Citizenship in Sex Trafficking. Palgrave

- Day, Sophie (2010): The re-emergence of 'trafficking': sex work between slavery and freedom, i: Journal of the Royal Anthropological Institute 16(4).

- Doezema, Jo (2010): Sex Slaves and Discourse Masters: The Construction of Trafficing. Zed Books, London.

- EU (2010): Forslag til EuropaParlamentets og Rådets direktiv om forebyggelse og bekompelse of menneskehandel og beskyttelse af ofrene herfor 2002/629/RIA (29.3.2010).

- Global Alliance Against Trafficking in Women (2011): What is the Cost of a Rumor? Lokaliseret 
14/11/2012 på http://www.gaatw.org/publications/WhatstheCostofaRumour.11.15.2011.pdf

- Gould, Chandre (2010): Moral Panic, Human Trafficking and the 2010 Soccer World Cup, i: $A g$ enda: Empowering Women for Gender Equity 24(85).

- Holm, Maibritt Gamborg (2006): Nigerianske kvinder i prostitution i Danmark: Migranter, sexarbejdere og midt $i$ mellem. Speciale. Roskilde Universitet.

- Hope for the Sold (2010): Controvery at the FIFA World Cup: Is There Really a Link Bettween Sporting Events and Traffiking? Lokaliseret 12/6/2012 på http://hopeforthesold.com/controversy-at-the-fifa-world-cup-is-there-really-alink-between-sporting-events-trafficking/

- IOM (2006): Trafficking in Human Beings and the 2006 World Cup in Germany, International Organization for Migration. Lokaliseret 12/6/2012 på http://www.iom.int/jahia/webdav/shared/ shared/mainsite/projects/documents/World_Cu p_2006_CT_Draft_Report.pdf

- Kempadoo, Kamala (2005): Trafficking and Prostitution Reconsidered: New Perspectives on Migration, Sex Work, and Human Rights. Paradigm Publishers, New York.

- Madsen, Agnete Birger (2008): Den hvide slavehandel $i$ Danmark 1870-1925. Virkelighed og myter. Kvindemuseet, København.

- Rothstein, Klaus (2006): VM i kvindehandel. Weekendavisen 9/6/2006.
- Rørbech, Mikala Satiya (2010): VM i sex og menneskehandel. Information 8/6/2010.

- Sharma, Nadita (2003): Travel Agency: A Critique of Anti-Trafficking Campaigns, i: Refuge $21(3)$.

- Socialministeriet (2011): Handlingsplan til bekampelse af menneskehandel 2011-2014. Socialministeriet, København.

- Spanger, Marlene (2011): Human Trafficking as a Lever for Feminist Voices? Transformations of the Danish Policy Field of Prostitution, i: Critical Social Policy 31(4).

- Sxhl, Thomas (2006): Regeringen svigter ofre for kvindehandel. Lokaliseret 12/6/2012 på http://forsiden.3f.dk/article/20060310/NYHEDER/60310002/2140/temal

- Tromborg, Marie (2012): Mange flere handlede kvinder i Danmark på to år, i: MetroXpress.

Lokaliseret 10/10/2012 på http://www.metroxpress.dk/nyheder/mange-flere-handlede-kvinderi-danmark-pa-toar/KObleo!tRj8ZGpPag816/?stop_mobi=yes - Weitzer, Ronald (2007): The Social Construction of Sex Trafficking: Ideology and Institutionalization of a Moral Crusade, i: Politics \& Society 35(3).

Christian Groes, adjunkt

Institut for Kultur og Identitet

Roskilde Universitet 